\title{
Micropropagation of Tulip via Somatic Embryogenesis
}

\author{
Małgorzata Podwyszyńska ${ }^{\circledR}$ and Agnieszka Marasek-Ciolakowska * \\ Department of Applied Biology, Research Institute of Horticulture, Konstytucji 3 Maja 1/3 Str., \\ 96-100 Skierniewice, Poland; malgorzata.podwyszynska@inhort.pl \\ * Correspondence: agnieszka.marasek@inhort.pl
}

Received: 7 October 2020; Accepted: 24 November 2020; Published: 25 November 2020

check for updates

\begin{abstract}
An effective method of tulip regeneration via somatic embryogenesis (SE) was developed. Explants, flower stem slices excised from cooled bulbs were incubated in darkness on MS modified media containing auxins alone (2,4-dichlorophenoxyacetic acid-2,4-D, 1-naphthalene acetic acid-NAA and 4-amino-3,5,6-trichloro-2-pyridine carboxylic acid-picloram) or combined with thidiazuron (TDZ) at 0.1 and $0.5 \mathrm{mg} \mathrm{L}^{-1}$. Yellowish-white callus with a granular structure was developed in the presence of all auxins on the cut surface from the tissues of the vascular bundles. From this, lines of embryogenic calli were derived. The addition of TDZ to the medium with auxins significantly stimulated somatic embryo formation. Cyclic and the most intensive proliferation of embryogenic callus as well as embryo formation was obtained in the presence of 2,4-D at $0.1 \mathrm{mg} \mathrm{L}^{-1}$ combined with TDZ at $0.5 \mathrm{mg} \mathrm{L}^{-1}$. Addition of proline enhanced either callus proliferation rate or frequency of embryo formation. The best quality embryos with cotyledons longer than $10 \mathrm{~mm}$ able to form bulbs were recorded when TDZ was replaced with 6-benzylaminopurine (BAP) at the concentration of $0.1 \mathrm{mg} \mathrm{L}^{-1}$. Histomorphology showed that the development of somatic embryos could have either external or internal origins. Embryos of external origin were initiated by cell division on the edge of embryogenic calli. Embryos of internal origin resulted from the division of parenchyma cells inside the tissue. Embryonic cells were characterized by their small volume, regular shape, dense cytoplasm and large nuclei. The globular embryos were covered by a distinct layer of periderm. Then, the embryos developed into structures having leaf-shaped cotyledons with a procambial strand and a sideward-orientated meristem of the vegetative apex (stolon). Cotyledon embryos did not show vascular connections with the parent tissue, and they did not develop embryonic roots.
\end{abstract}

Keywords: growth regulators; histological analysis; Tulipa gesneriana L.; somatic embryos

\section{Introduction}

Tulips are among the leading cut flowers produced [1,2]. The development of a new cultivar is time-consuming and expensive. Around 20-25 years can pass from the selection of the first seedlings to the propagation of a new cultivar into 10,000 bulbs and its appearance on the market [1]. By using an in vitro propagation method, this period can be shortened. However, in vitro tulip regeneration systems described in the available literature have been not efficient enough. In the 1980s, 1990s and in the first years of the 21st century, much information was generated on the direct regeneration of shoots or microbulbs on the initial explants such as the bulb scales, vegetative buds and flower stems, with the latter showing highest regenerative potential [3-8]. These methods were not the systems based on the cyclic multiplication of adventitious shoots or bulbs and allowed obtaining at most about 200 microbulbs from one donor bulb. Maślanka and Bach [9] demonstrated a high regenerative potential for seedling fragments as initial explants of Tulipa tarda. This method is based also on the direct regeneration of adventitious shoots, and it could be used successfully to reproduce wild tulip species, e.g., those endangered with extinction. Recently, a similar in vitro propagation system has been 
reported for T. suaveolens by Kritskaya et al. [10]. However, the use of seedlings as initial explants does not allow it to be used in the production of tulip cultivars, as these are highly heterozygous genotypes and require explants obtained from vegetative organs for cloning. Several years ago, we developed the method of tulip micropropagation based on cyclic multiplication of adventitious shoots. This system is characterized by higher efficiency and it is possible to produce approximately 1000 microbulbs from a few bulbs over 2-3 years [11-14]. The method is based on the regeneration of somatic embryos from fragments of a flower stem, then adventitious shoot regeneration on stolon tips developed from the embryos, and further cyclic multiplication of adventitious shoots for about two years on medium containing $N$-phenyl- $N^{\prime}-1,2,3$-thidiazol-5-yl urea (TDZ), isopentenyl adenosine (iP) and 1-naphthalene acetic acid (NAA). This micropropagation method has been used either for virus elimination using chemotherapy or the propagation of healthy material of several tulip cultivars [15] and for tetraploid induction [16].

Further progress in enhancing the regeneration efficiency of tulip can be achieved using systems based on somatic embryogenesis (SE). SE is a developmental process enabling non-zygotic plant cells (somatic cells) to form an embryo and then regenerate the whole plant [17]. The first somatic embryo formation in vitro was reported for carrot over 60 years ago [18]. Since then, the process of plant regeneration via SE has been studied on many levels: morphological, histological, hormonal or genetic regulation, and various SE-based regeneration systems have been developed for numerous plan species [19-23]. Somatic embryos may arise directly on the initial explants (fragments of young organs such as shoots, vegetative buds, leaves and flower stalks) or indirectly via the embryogenic callus. The various SE systems, regardless of the species, consist of three to four stages. In a direct SE, the stages are as follows: (1) induction of embryo formation, (2) embryo development and (3) plant regeneration from the embryo; whereas in an indirect SE: (1) initiation of embryogenic callus, (2) callus proliferation, (3) embryo formation and (4) plant regeneration. The former is used rather for various breeding purposes and the latter is more suitable for commercial propagation. SE is influenced by several factors such as genotype, explants source, plant growth regulators (PGRs) with auxins playing a key role, and organic additives as casein hydrolysate, glutamine, proline or polyamines [19].

The SE of tulip was first demonstrated by Gude and Dijkema [24]. They induced somatic embryos on flower stem explants on a medium with 5 or $50 \mu \mathrm{M}$ 2,4-dichlorophenoxyacetic acid (2,4-D) or 4-amino-3,5,6-trichloro-2-pyridine carboxylic acid (picloram). Bach and Ptak [25] and Ptak and Bach [26] reported the possibility of using the method based on somatic embryogenesis for tulip propagation by the formation of numerous embryos on ovary segments and flower stem fragments, respectively, isolated from cooled bulbs and incubated on an MS medium supplemented with $25 \mu \mathrm{M}$ of picloram and $0.5 \mu \mathrm{M}$ 6-benzylaminopurine (BAP). Further development of embryos in plants was conducted in the presence of $5 \mu \mathrm{M}$ BAP and $0.5 \mu \mathrm{M}$ NAA. The formation of bulbs was achieved after the embryos were cultured in a sucrose-rich medium and treated with a low temperature of $5{ }^{\circ} \mathrm{C}$ to induce the bulbing process. Subsequent studies of this research team showed that the use of salicylic acid (an inhibitor of ethylene biosynthesis) together with 2-chloroethylphosphonic acid (ethephon) stimulated the development of leaves at the cotyledonary phase [27]. In turn, abscisic acid (ABA), as well as the inhibitor of its biosynthesis-fluridone-did not significantly influence the shoot development of the embryos [28]. It seems that the continuation of research on the optimization of individual stages of tulip propagation in vitro via SE could be highly effective.

The current study aimed to develop an effective method of tulip regeneration utilizing SE for the rapid multiplication of healthy material of new cultivars and other breeding purposes. In our research, we focused on direct SE as well cyclic embryogenic callus proliferation and stimulation of embryo production from such calli, then the development of plantlets and finally bulbs, the final product of tulip micropropagation. In addition, histological analyses were conducted to confirm the nature of the callus and to clarify the development of embryos. 


\section{Material and Methods}

\subsection{Plant Material}

The tulip cultivars 'Blue Parrot', 'Apeldoorn' and 'Prominence' were used in the research to induce callus and direct somatic embryo formation. For further studies on embryogenic callus proliferation and embryo development, the calli of 'Blue Parrot' were used. This is because this cultivar produced during the stabilization SE stage, the highest amount of embryogenic calli that made it possible to conduct further experiments.

The research included optimization of the conditions in the successive stages of SE: (1) induction of callus and direct somatic embryo formation, (2) multiplication of embryogenic callus and (3) induction of somatic embryo formation from callus and further development of an embryo into plantlets and finally bulb formation.

\subsection{Induction of Callus and Direct Somatic Embryo Formation}

The initial explants were isolated from bulbs cooled from September for 16 weeks at $5{ }^{\circ} \mathrm{C}$ and then grown in the darkness for 10 days at $15^{\circ} \mathrm{C}$ to obtain flower stems $2-5 \mathrm{~cm}$ long. The bulbs were surface disinfected with 3\% chloramine $\mathrm{T}$ for $20 \mathrm{~min}$, washed in sterile water, then disinfected again with $0.1 \% \mathrm{HgCl}_{2}$ for $10 \mathrm{~min}$ and washed 3 times in sterile water. The flower stems were isolated and cut into $2 \mathrm{~mm}$ slices which were then incubated in darkness at $20^{\circ} \mathrm{C}$ for 2.5 months on a basal medium containing Murashige and Skoog [29] mineral salts and organic compounds: $10 \mathrm{mg} \mathrm{L}^{-1}$ thiamine, $1 \mathrm{mg} \mathrm{L}^{-1}$ pyridoxine, $5 \mathrm{mg} \mathrm{L}^{-1}$ nicotinic acid, $10 \mathrm{mg} \mathrm{L}^{-1}$ glycine, $100 \mathrm{mg} \mathrm{L}^{-1}$ glutamine, $1 \mathrm{~g} \mathrm{~L}^{-1}$ casein hydrolysate, $0.8 \%$ Bactoagar, $3 \%$ sucrose; this basal medium was supplemented with auxins alone, such as 2,4-D, picloram or NAA and combined with TDZ at 0.1 and $0.5 \mathrm{mg} \mathrm{L}^{-1}$. Auxin concentrations were selected based on preliminary study and were applied as follows: 2,4-D and picloram at $2.5 \mathrm{mg} \mathrm{L}^{-1}$ and NAA at $10 \mathrm{mg} \mathrm{L}^{-1}$. Callus production and the number of visible embryos (longer than $3 \mathrm{~mm}$ ) per initial explant were estimated after 2.5-month initial culture. Callus formation was assessed according to a 0-3 scale: 0 -no callus growth, 1 -the presence of callus in 2-3 points on the explant, 2-callus on the surface of the entire epidermis and 3-callus on the surface of the entire explant.

The forming callus was then transferred monthly to the same fresh media as used in the initial stage to stimulate callus growth or embryo development. Stabilized embryogenic callus was obtained after 6 months only when cultures were grown on the medium supplemented with $2.5 \mathrm{mg} \mathrm{L}^{-1} 2,4-\mathrm{D}$ and 0.1 and $0.5 \mathrm{mg} \mathrm{L}^{-1} \mathrm{TDZ}$. The amount of callus sufficient to conduct further research, was achieved only for 'Blue Parrot'. Such callus was used for further experiments. The above-described basal medium ( $15 \mathrm{~mL}$ in $50-\mathrm{mL}$ Erlenmeyer flasks) and culture conditions, the temperature of $20^{\circ} \mathrm{C}$ and darkness, were used throughout the study except where stated otherwise.

\subsection{Embryogenic Callus Production}

The effect of proline (100 and $200 \mathrm{mg} \mathrm{L}^{-1}$ ) and Tytanit ${ }^{\circledR}$ (InterMag, Osiek, Poland: 10 and $100 \mathrm{mg} \mathrm{L}^{-1}$ ) on embryogenic callus production were studied. Calli were subcultured twice at one-month intervals on basal media supplemented with $2.5 \mathrm{mg} \mathrm{I}^{-1}$ 2,4-D and $0.1 \mathrm{mg} \mathrm{L}^{-1} \mathrm{TDZ}$, proline and Tytanit ${ }^{\circledR}$, in darkness. In the control, the medium did not contain proline or Tytanit ${ }^{\circledR}$. Four $100 \mathrm{mg}$ callus clumps were placed in 50-mL Erlenmeyer flasks, with four flasks for each treatment, i.e., $4 \times 0.1 \mathrm{~g}$ callus $\times 4$ flasks $=1.6 \mathrm{~g}$ callus per treatment. An increase in callus fresh mass (FM) was calculated as the ratio of the final to the initial callus FM at the end of the second subculture.

\subsection{Somatic Embryo Formation from Callus and Their Further Development}

In the first experiment, the influence of tyrosine $\left(100 \mathrm{mg} \mathrm{L}^{-1}\right)$ and proline $\left(100,200\right.$ and $\left.400 \mathrm{mg} \mathrm{L}^{-1}\right)$ as well as a white and red light on the formation and development of somatic embryos, was investigated. Embryogenic calli with developing embryos were transferred to fresh medium four times at two-month intervals. The media contained TDZ $\left(0.1 \mathrm{mg} \mathrm{L}^{-1}\right)$ and 2,4-D $\left(0.1 \mathrm{mg} \mathrm{L}^{-1}\right)$ and above-mentioned amino 
acids. In the control, the medium was devoid of these amino acids. During the first two subcultures, the embryogenic callus cultures were carried out in the darkness and for the next two subcultures, in cool white light (Philips TLD 36 W/95) or red light (Philips TLD 36 W/15 with a wavelength peak of about $660 \mathrm{~nm}$ ), both at PPFD of $30 \mu \mathrm{mol} \mathrm{m}^{-2} \mathrm{~s}^{-1}$ and a $16 \mathrm{~h}$ photoperiod. The number of somatic embryos was recorded at the end of the experiment.

In the second experiment, the effects of growth regulators, TDZ, BAP, m-Topolin $(\mathrm{m}-\mathrm{T})$ and gibberellic acid $\left(\mathrm{GA}_{3}\right)$ (see Table 1 ) on the formation and development of somatic embryos were examined. Embryogenic callus was sub-cultured four times at two-month intervals in darkness, on the basal medium supplemented with the above-mentioned PGRs and $100 \mathrm{mg} \mathrm{L}^{-1}$ proline. Meanwhile, 2,4-D was used at a concentration of $0.1 \mathrm{mg} \mathrm{L}^{-1}$ in the first subculture and $0.01 \mathrm{mg} \mathrm{L}^{-1}$ in the remaining subcultures. Embryo numbers were counted at the end of each subculture. The amount of callus and replications were similar to those described for the experiment on callus production.

The post effect of the PGR treatments on bulb formation was also examined. The slightly modified procedure of the three-step bulb formation process and further bulb cultivation, developed in earlier studies, was applied $[13,14]$. Briefly, to prepare embryo cultures for the bulb formation process, the clusters of embryos with cotyledons longer than $10 \mathrm{~mm}$ were transferred to basal medium (in 100-mL Erlenmeyer flasks) supplemented with $100 \mathrm{mg} \mathrm{L}^{-1}$ proline, containing 2,4-D and BAP both at $0.1 \mathrm{mg} \mathrm{L}^{-1}$, and cultured in standard light conditions (PPFD of $40 \mathrm{~mol} \mathrm{~m}^{-2} \mathrm{~s}^{-1}$ ) at a $16 \mathrm{~h}$ photoperiod. Two months later, $20 \mathrm{~mL}$ of liquid MS medium [13] supplemented with NAA and cyclopropyl-(4-methoxyphenyl)-pyrimidin-5-ylmethanol (ancymidol), both at $1 \mathrm{mg} \mathrm{L}^{-1}$ were added to flasks with plantlet cultures. After an additional six weeks on such a two-phase medium, to induce bulb formation, the intact plantlet clusters were transferred to 100-mL Erlenmeyer flasks with $40 \mathrm{~mL}$ of a bulbing MS medium containing $7 \%$ sucrose and cooled in darkness for 12 weeks at $5{ }^{\circ} \mathrm{C}$. Finally, flasks with plantlet culture were placed for 10 weeks at $23^{\circ} \mathrm{C}$ in standard light conditions for bulb formation. Then, the bulbs were washed and stored at room temperature for four weeks. The number of bulbs per $100 \mathrm{mg}$ of callus and the total number of bulbs per treatment (obtained from an initial $1.6 \mathrm{~g}$ of embryogenic callus) were counted. Bulbs were then planted to peat medium at $9{ }^{\circ} \mathrm{C}$ for 3 months and cultivated in an insect-proof tunnel in a field.

\subsection{Microscopic Analysis}

For histological observation, fragments of callus and regenerating structures were fixed in chromic acid, acetic acid and formalin (CrAF) solution for $48 \mathrm{~h}$ at room temperature, dehydrated through an increasing alcohol series (70, 80, 90 and 100\%), and embedded in paraffin. Longitudinal sections, $15 \mu \mathrm{m}$ thick, were cut with a rotary microtome (Leica, Wetzlar, Germany) and stained with safranin ( $1 \%$ prepared in ultrapure water) followed by fast green ( $1 \%$ prepared in $95 \%$ ethanol). The sections were mounted in Canada balsam and analyzed using a light microscope (Eclipse 80i, Nikon, Tokyo, Japan) with imaging software NIS-Elements BR ver. 4.00 (Nikon Instruments Inc., Tokyo, Japan) for photo documentation.

\subsection{Statistical Analyses}

Data were subjected to analysis of variance (ANOVA) and the means were compared by Duncan's test at $p<0.05$. In successive experiments, the following ANOVA models were used: (Section 2.2) the effects of auxin and TDZ, depending on cultivar, on the induction of callus and direct embryo formation-the three-way ANOVA; (Section 2.3) the effects of proline and Tytanit ${ }^{\circledR}$ on embryogenic callus production-one-way ANOVA; (Section 2.4, 1st experiment) the effects of amino acids and light quality on somatic embryo formation - the two-way ANOVA; (Section 2.4, 2nd experiment) effects of PGRs in successive subcultures on embryo production - the two-way ANOVA, and the bulb formation was analyzed using one-way ANOVA; significance of the effects were confirmed by the $P$ (probability) value of the statistic from ANOVA, $p \leq 0.05$ meant that the effect was significant. All calculations were done with STATISTICA package (StatSoft v. 13.1). 


\section{Results}

\subsection{Callus Induction and Direct Embryogenesis}

Callus formation was observed on initial explants in the presence of all auxins (Figures 1 and 2). A white and soft callus was developed from epidermal cells. Yellowish-white callus with a granular structure was developed on the cut surface from the tissues of the vascular bundles. From this, the lines of embryogenic calli were derived. Three-way ANOVA revealed that the cultivar, auxin type and TDZ significantly influenced the callus growth (Tables S1 and S2; Figures 1 and 2). The addition of TDZ to the medium with auxins significantly stimulated callus formation in 'Apeldoorn' irrespective of the auxin type. In 'Prominence', significantly higher callus production was recorded on media containing picloram and NAA, regardless of TDZ presence, compared to all 2,4-D treatments. TDZ combined with 2,4-D inhibited callus formation in this cultivar. In 'Blue Parrot', the higher callus amounts were observed for 2,4-D and NAA applied alone while TDZ, especially at higher concentration, significantly reduced callus formation on initial explants regardless of auxin type.
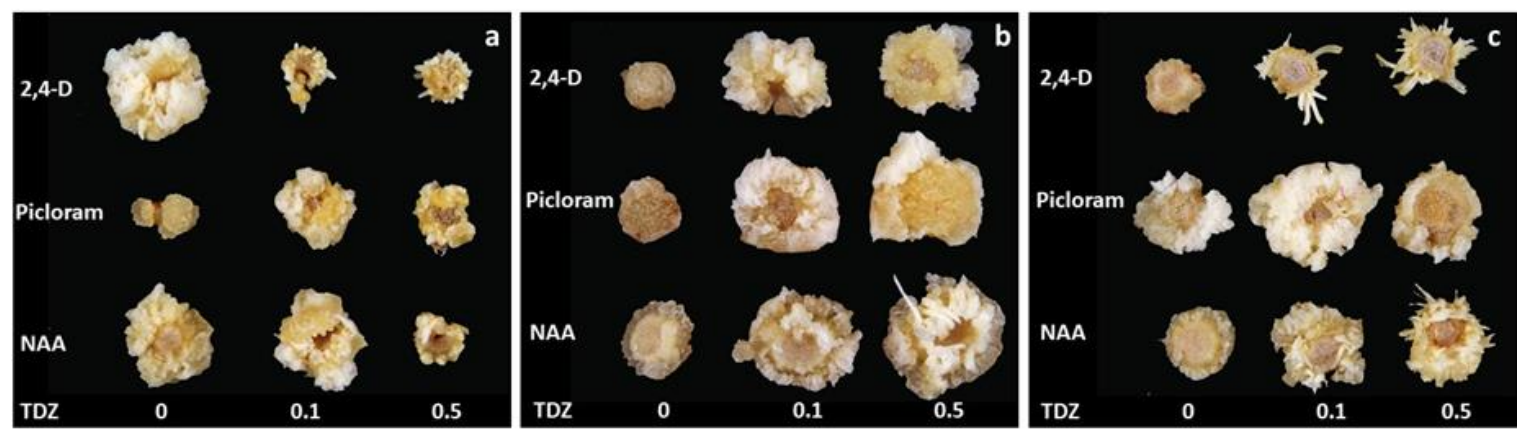

Figure 1. Callus and somatic embryos formed in the process of direct somatic embryogenesis on fragments of flower stems of tulip (a) ‘Blue Parrot', (b) 'Apeldoorn' (c) ‘Prominence', on auxin-containing media, from the top ( $\mathrm{mg} \mathrm{L}^{-1}$ ): 2.5 2,4-dichlorophenoxyacetic acid (2,4-D); 2.5 4-amino-3,5,6-trichloro-2-pyridine carboxylic acid (picloram); 10 1-naphthalene acetic acid (NAA) and $N$-phenyl- $N^{\prime}-1,2,3-$ thidiazol-5-yl urea (TDZ), from the left $\left(\mathrm{mg} \mathrm{L}^{-1}\right)$ : 0, 0.1 and 0.5; after 2.5-month initial culture.

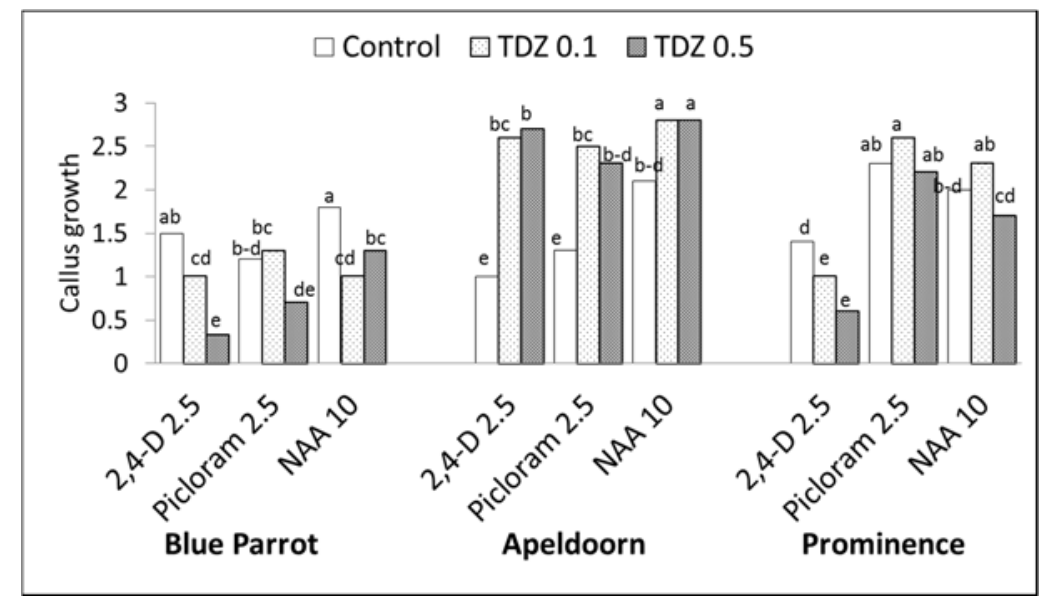

Figure 2. Effect of auxins and TDZ on callus induction on tulip initial explants (fragments of flower stem) assessed according to a 0-3 scale: 0 -no callus growth, 1-the presence of callus in 2-3 points on the explant, 2-callus on the surface of the entire epidermis and 3-callus on the surface of the entire explant; plant growth regulator (PGR) concentrations in $\mathrm{mg} \mathrm{L}^{-1}$, control medium without TDZ; three-way ANOVA, $p<0.02$ for all of the factors (cultivar, auxin and TDZ concentration) and their interactions; means for each cultivar marked with the same letter did not differ significantly at $p=0.05$; Duncan's test. 
Based on three-way ANOVA, the cultivars differed significantly in capacity for somatic embryogenesis and this process was highly influenced by auxin type and TDZ presence (Tables S1 and S2). The highest average number of embryos was obtained for 'Prominence', then 'Blue Parrot', and the least for 'Apeldoorn', 8.5, 4.0 and 0.7 respectively. The addition of TDZ to auxin containing media strongly stimulated SE. The highest number of embryos, approximately 24, was recorded for 'Prominence' in the presence of 2,4-D combined with TDZ, irrespective of its concentration (Figures 1c and 3). For NAA combined with TDZ 0.1 and $0.5 \mathrm{mg} \mathrm{L}^{-1}, 11.3$ and 16.3 embryos per explant were formed, respectively. A strong response was also observed for 'Blue Parrot' on medium containing $0.5 \mathrm{mg} \mathrm{L}^{-1} \mathrm{TDZ}$ combined with 2.4-D or NAA resulting in 12.9 and 7.7 embryos, respectively (Figures $1 \mathrm{a}$ and 3). The weaker reactions of all cultivars were observed with picloram.

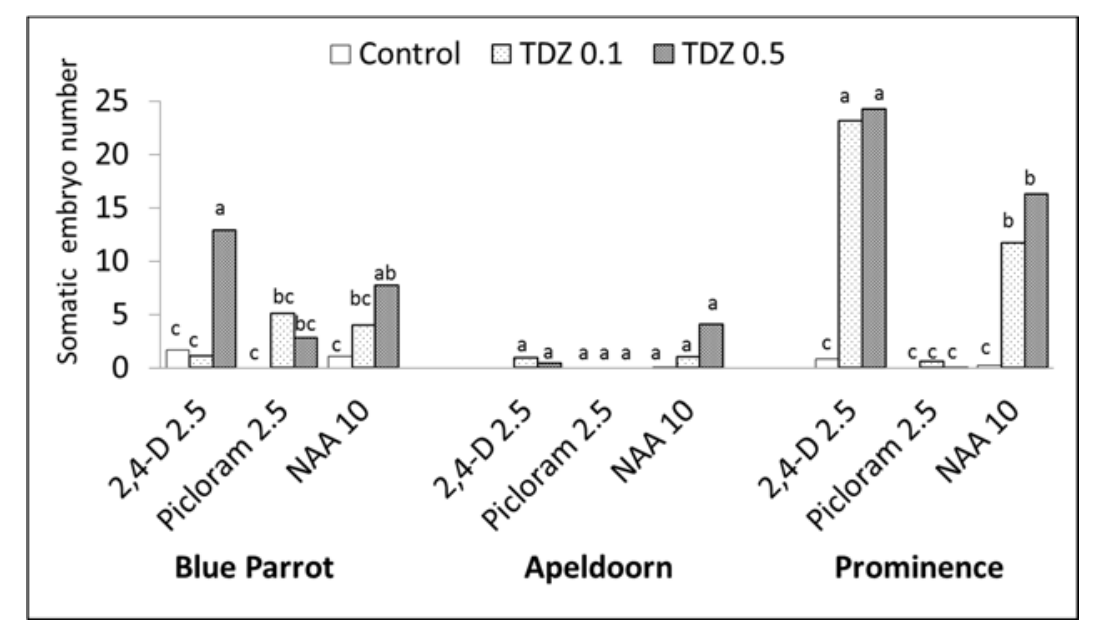

Figure 3. Effect of auxins and TDZ on the number of somatic embryos $>3 \mathrm{~mm}$ per initial explant (fragments of lower stem) during a direct regeneration; PGR concentrations in $\mathrm{mg} \mathrm{L}^{-1}$, control medium without TDZ; three-way ANOVA, $p<0.001$ for all of the factors (cultivar, auxin and TDZ concentration) means for each cultivar marked with the same letter did not differ significantly at $p=0.05$; Duncan's test.

Stages of direct somatic embryogenesis in tulip 'Prominence' on induction media containing $2.5 \mathrm{mg} \mathrm{L}^{-1}$ picloram and $0.5 \mathrm{mg} \mathrm{L}^{-1} \mathrm{TDZ}$ are shown in Figure 4. Figure $4 \mathrm{a}, \mathrm{b}$ shows an early stage of embryo development. Somatic globular embryos were mainly composed of small compact meristematic cells, characterized by a dense cytoplasm and nucleus. Globular embryos formed a typical single layer of protoderm on their surface (Figure $4 \mathrm{~b}$ ). Then, the embryos developed into characteristic structures: cotyledons growing upwards, in the opposite direction an apical bud formed at the base of the cotyledon (Figure $4 \mathrm{c}, \mathrm{d}$ ). Histological analysis confirmed the presence of a leaf-shaped cotyledon with a procambial strand and a sideward-orientated meristem of the vegetative apex (Figure $4 \mathrm{~d}$ ). However, no vascular connection of the embryo with parental tissue was observed. In addition, no development of the embryonic root was observed. Further development of the embryos was obtained in white light on a medium containing TDZ $\left(0.1 \mathrm{mg} \mathrm{L}^{-1}\right)$ and 2,4-D $\left(0.1-0.4 \mathrm{mg} \mathrm{L}^{-1}\right)$ (Figure 4e,f). Embryos produced shorter or longer stolons (dropper) and on their apex, vegetative buds developing in shoots were formed. 

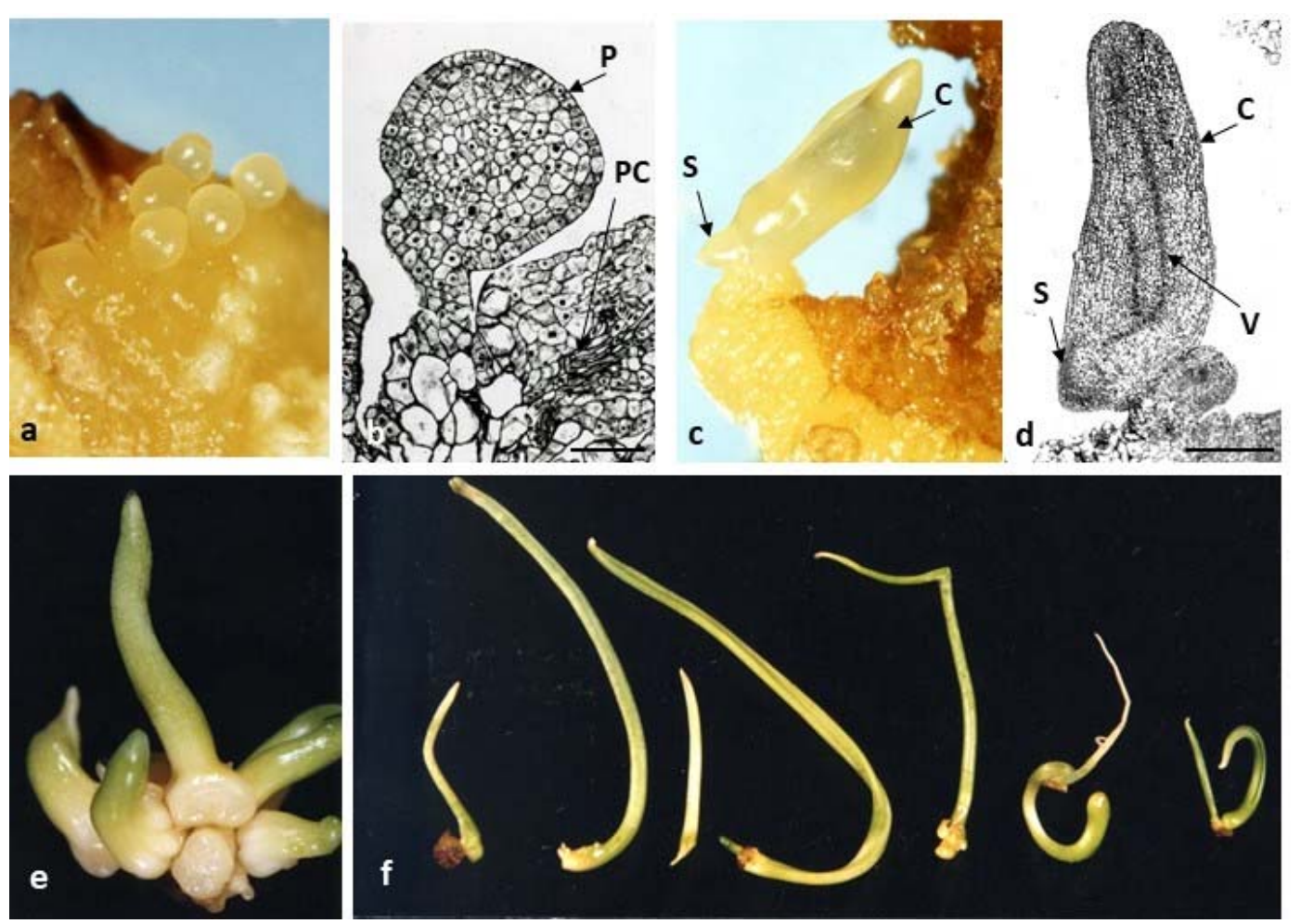

Figure 4. Direct somatic embryogenesis in tulip 'Prominence' on induction medium containing picloram $2.5 \mathrm{mg} \mathrm{L}^{-1}$ and TDZ $0.5 \mathrm{mg} \mathrm{L}^{-1}$, after two-month initial culture. (a) Globular embryos in Stereoscope Microscope. (b) Microscopic picture of a longitudinal section of a globular embryo; $\mathrm{P}$-protoderm, PC—procambium $($ Bar $=100 \mu \mathrm{m}$ ). (c) Embryos forming cotyledons growing upwards with an apical bud formed at their base. (d) Longitudinal section of the embryo at the cotyledonary phase C-cotyledon; V-vascular tissue; S-apical bud $($ Bar $=200 \mu \mathrm{m})$. (e) Cluster of embryos at the cotyledonary phase. (f) Shoots developed from embryos with cotyledonary leaves and stolons.

\subsection{Callus Production}

Callus proliferation of 'Blue Parrot' was significantly stimulated by proline $\left(100 \mathrm{mg} \mathrm{L}^{-1}\right)$ alone or combined with Tytanit ${ }^{\circledR}\left(10 \mathrm{mg} \mathrm{L}^{-1}\right)$ (Figure 5).

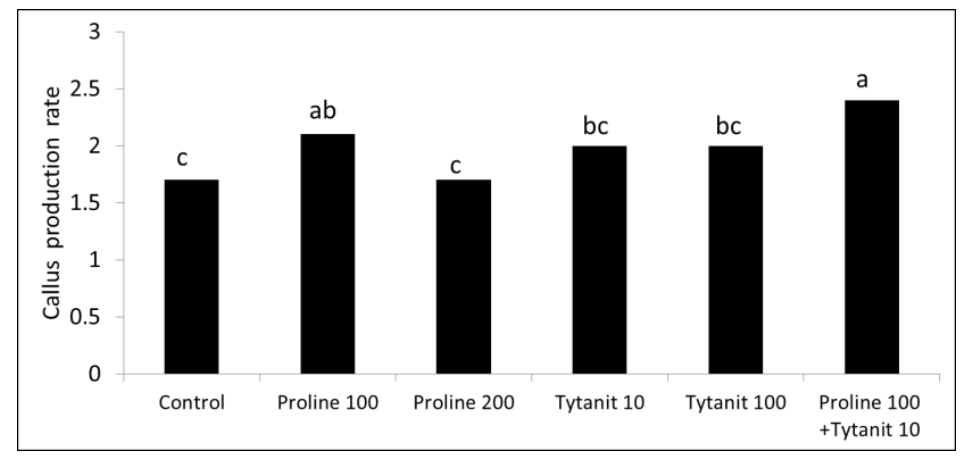

Figure 5. Effect of proline and Tytanit ${ }^{\circledR}$ on callus production of tulip 'Blue Parrot'; proline and Tytanit ${ }^{\circledR}$ concentrations in $\mathrm{mg} \mathrm{L}^{-1}$, control medium without these compounds; callus production rate was calculated as the ratio of the final to the initial callus FM; one-way ANOVA, $p<0.001$; means marked with the same letter did not differ significantly at $p=0.05$; Duncan's test.

\subsection{Somatic Embryo Formation from Callus and Their Further Development}

Two-way ANOVA showed that both the light quality and amino acids significantly influenced embryo development with $p<0.01$ for both of the factors and their interactions. 'Blue Parrot' embryo 
formation was stimulated by proline at the concentration of $100 \mathrm{mg} \mathrm{L}^{-1}$ in white light applied during the last two subcultures when shoot development in embryos was more advanced (Figure 6). In this treatment, 6.6 somatic embryos were obtained, while in the control, 5.2. Tyrosine did not influence embryo number. Red light revealed generally an inhibitory SE effect. Based on two-way ANOVA, the embryo number per $100 \mathrm{mg}$ callus obtained under red light was on average significantly lower (4.0) compared to white light treatment (5.2). The significantly lower embryo numbers under the red light compered to white light were observed for proline treatments at 100 and $400 \mathrm{mg} \mathrm{L}^{-1}$.

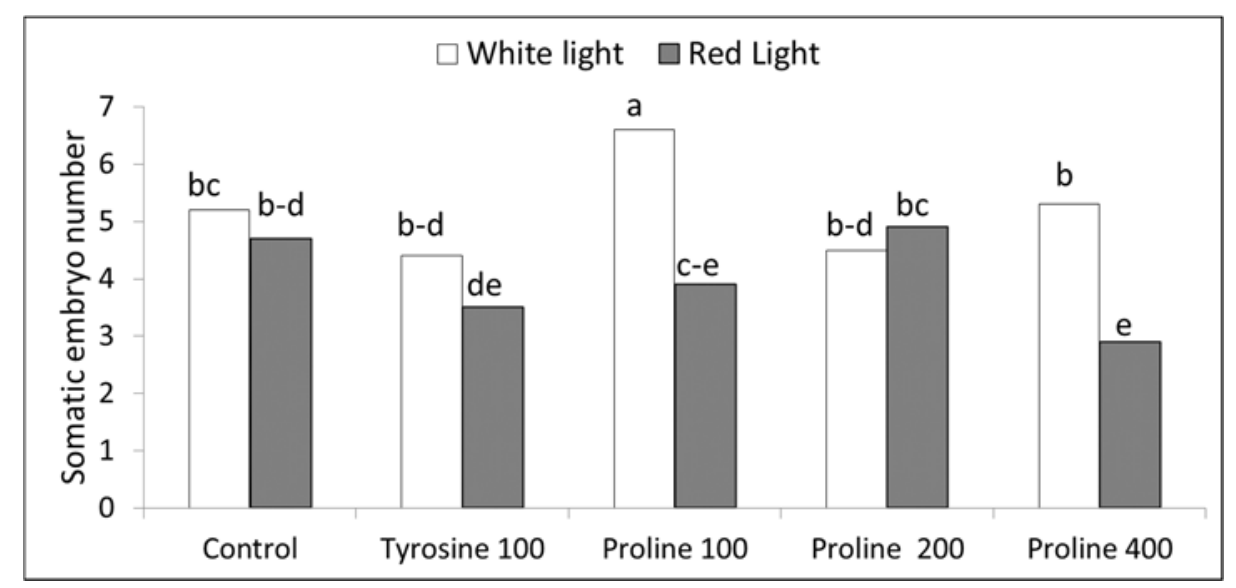

Figure 6. The effects of amino acids and light quality on the number of somatic embryos per $100 \mathrm{mg} \mathrm{L}^{-1}$ of tulip 'Blue Parrot'; two-way ANOVA, $p<0.01$ for both of the factors (light quality and amino acid) and their interactions; means marked with the same letter did not differ significantly at $p=0.05$; Duncan's test.

Results of the second experiment (conducted in darkness) showed that the higher total numbers of embryos (from approx. 44 to 54 embryos per $100 \mathrm{mg}$ callus) were obtained when the medium contained TDZ at $0.5 \mathrm{mg} \mathrm{L}^{-1}$ alone or TDZ at $0.1 \mathrm{mg} \mathrm{L}^{-1}$ combined with BAP or m-Topolin each at $0.5 \mathrm{mg} \mathrm{L}^{-1}$ (Table 1, Figure 7a,b). The highest total embryo number, 94.3, was recorded at the end of the second subculture for TDZ at $0.5 \mathrm{mg} \mathrm{L}^{-1}$. In the following cycles, however, the number of embryos decreased to 38 at the last subculture and was comparable to that obtained for the combination of $0.1 \mathrm{mg} \mathrm{L}^{-1} \mathrm{TDZ}$ with BAP or m-Topolin. $\mathrm{GA}_{3}$ revealed generally an inhibitory effect on $\mathrm{SE}$, especially when applied at higher concentration of $1 \mathrm{mg} \mathrm{L}^{-1}$ (Table 1). The average total embryo numbers for $\mathrm{GA}_{3}$ used at 0.1 and $1 \mathrm{mg} \mathrm{L}^{-1}$ were on average 23.3 and 8.8 , respectively and were significantly lower when compared to the best mentioned above treatments with TDZ, BAP and m-Topolin. Moreover, the embryo numbers differed significantly between subcultures. The lowest total embryo number was observed in the 1st subculture, on average 19.2 embryos per $100 \mathrm{mg}$ callus, twice as many in the second and third subcultures, and in the fourth subculture, the total number of embryos decreased to an average of about 30 embryos per $100 \mathrm{mg}$ callus.

The best quality embryos with cotyledons longer than $10 \mathrm{~mm}$, most suitable for bulb formation, were obtained in the presence of BAP alone at the concentration of $0.1 \mathrm{mg} \mathrm{L}^{-1}$ (Table 2). In this treatment the highest number (32.5) of the embryos with longer cotyledons were recorded at the fourth subculture (Table 2, Figure 7c). Whereas, at the same time, 2.3 and 10 embryos were formed in the presence of TDZ at 0.1 and $0.5 \mathrm{mg} \mathrm{L}^{-1}$, respectively. The lowest numbers of embryos with longer cotyledons were obtained for $\mathrm{GA}_{3}$ at $1 \mathrm{mg} \mathrm{L}^{-1}$.

The production of embryos with longer cotyledons $(>10 \mathrm{~mm})$ increased from subculture to subculture and the higher embryo numbers were recorder in the last two subcultures, reaching an average of about 14 embryos per $100 \mathrm{mg}$ of callus. 

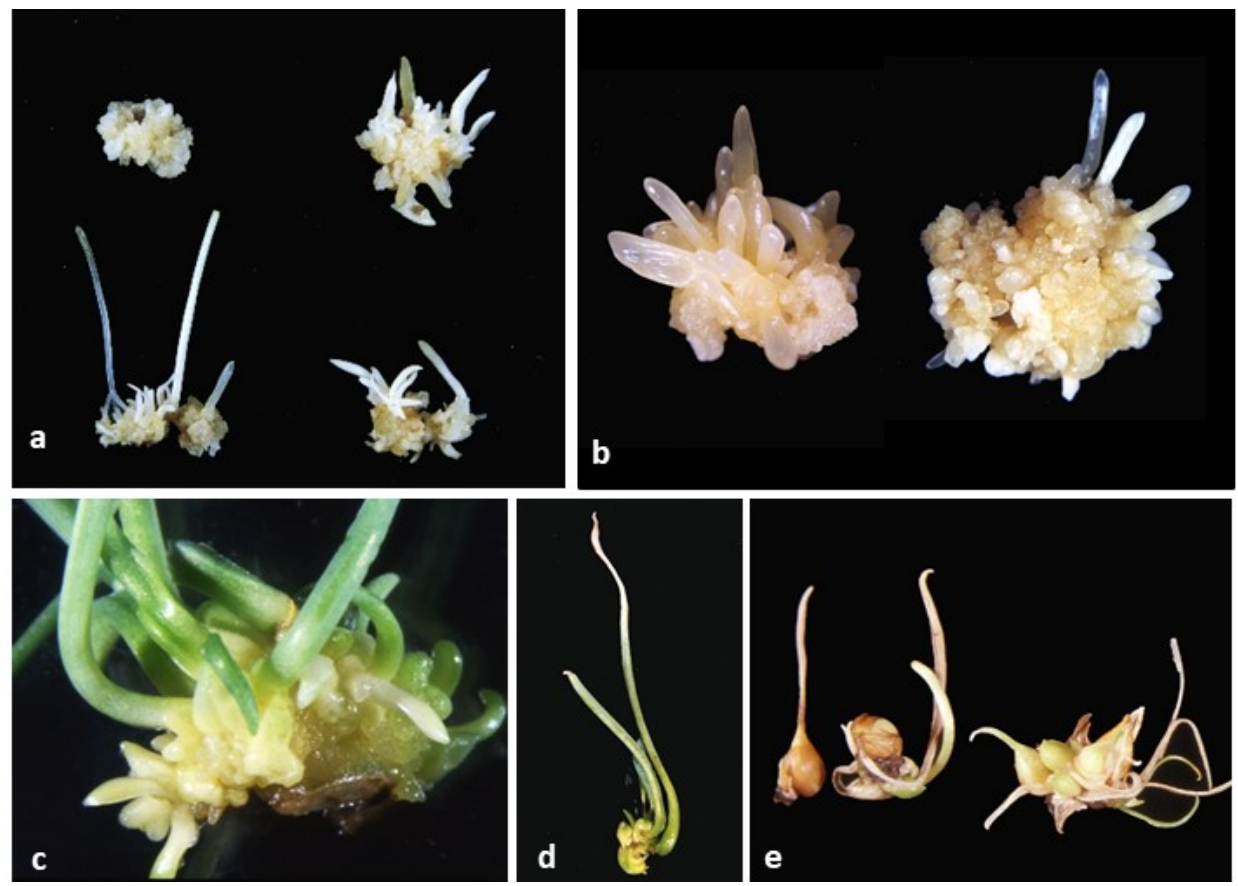

Figure 7. Somatic embryogenesis in callus cultures and the embryos developing into plantlets and then bulbs. (a) SE on media containing 2,4-D combined with TDZ (at the top) at the concentrations of 0.1 and $0.5 \mathrm{mg} \mathrm{L}^{-1}$ (from the left), 6-benzylaminopurine (BAP) at the bottom at the concentrations of 0.1 and $0.5 \mathrm{mg} \mathrm{L}^{-1}$ (from the left). (b) Embryogenic callus on media containing 2,4-D combined with $0.1 \mathrm{mg} \mathrm{L}^{-1} \mathrm{TDZ}$ and BAP at 0.1 (left) and $0.5 \mathrm{mg} \mathrm{L}^{-1}$ (right), after 2nd subculture. (c) Embryos with developed cotyledons at the stage of preparation for bulb formation; (d). Plantlets developed from embryos with the visible cotyledonary leaf growing up and at the opposite pole, the small stolon growing down, ready for induction of bulb formation. (e) Bulb formation 10 weeks after cooling.

Table 1. Effect of plant growth regulators (PGRs): $N$-phenyl- $N^{\prime}-1,2,3-$ thidiazol-5-yl urea (TDZ), 6-benzylaminopurine (BAP), m-Topolin (m-T) and gibberellic acid $\left(\mathrm{GA}_{3}\right)$, on the production of somatic embryos in successive subcultures; the basal medium contained 2,4-dichlorophenoxyacetic acid (2,4-D) at the concentration of $0.1 \mathrm{mg} \mathrm{L}^{-1}$ in the first subculture and 0.01 in the remaining subcultures.

\begin{tabular}{|c|c|c|c|c|c|}
\hline \multirow{2}{*}{$\begin{array}{l}\text { PGRs } \\
\left(\mathrm{mg} \mathrm{L}^{-1}\right)\end{array}$} & \multicolumn{5}{|c|}{$\begin{array}{l}\text { Total Number of Embryos at the End of Consecutive } \\
\text { Two-Month Subcultures per } 100 \mathrm{mg} \text { Callus }\end{array}$} \\
\hline & 1 & 2 & 3 & 4 & Mean \\
\hline TDZ 0.1 & $13.8 \mathrm{ab}$ & $34.3 \mathrm{~b}$ & $30.3 \mathrm{bc}$ & $18.5 \mathrm{bc}$ & $24.2 \mathrm{~d}$ \\
\hline TDZ 0.5 & $32.3 \mathrm{a}$ & $94.3 \mathrm{a}$ & $57.8 \mathrm{a}$ & $38.0 \mathrm{ab}$ & 55.6 a \\
\hline BAP 0.1 & $25.3 \mathrm{ab}$ & $38.8 \mathrm{~b}$ & $46.0 \mathrm{ab}$ & $37.0 \mathrm{ab}$ & $36.8 \mathrm{bc}$ \\
\hline BAP 0.5 & $20.0 \mathrm{ab}$ & $40.8 \mathrm{~b}$ & $38.0 \mathrm{ab}$ & $30.8 \mathrm{ab}$ & $32.4 \mathrm{~cd}$ \\
\hline TDZ 0.1 + BAP 0.1 & $19.4 \mathrm{ab}$ & $36.3 \mathrm{~b}$ & $43.3 \mathrm{ab}$ & $31.8 \mathrm{ab}$ & $32.6 \mathrm{~cd}$ \\
\hline TDZ 0.1 + BAP 0.5 & $13.5 \mathrm{ab}$ & $52.3 \mathrm{~b}$ & $54.5 \mathrm{a}$ & $55.3 \mathrm{a}$ & $43.9 \mathrm{~b}$ \\
\hline TDZ $0.1+$ m-T 0.1 & $13.0 \mathrm{ab}$ & $38.0 \mathrm{~b}$ & $40 \mathrm{ab}$ & $22.0 \mathrm{bc}$ & $28.3 \mathrm{~cd}$ \\
\hline TDZ $0.1+$ m-T 0.5 & $28.5 \mathrm{ab}$ & $61.0 \mathrm{~b}$ & $54.5 \mathrm{a}$ & $33.8 \mathrm{ab}$ & $44.4 \mathrm{~b}$ \\
\hline $\mathrm{TDZ} 0.1+\mathrm{GA}_{3} 0.1$ & $20.0 \mathrm{ab}$ & $30.0 \mathrm{bc}$ & $25.5 \mathrm{bc}$ & $20.0 \mathrm{bc}$ & $23.3 \mathrm{~d}$ \\
\hline $\mathrm{TDZ} 0.1+\mathrm{GA}_{3} 1$ & $6.5 \mathrm{~b}$ & $11.5 \mathrm{c}$ & $11.8 \mathrm{c}$ & $5.3 c$ & $8.8 \mathrm{e}$ \\
\hline Mean & $19.2 \mathrm{C}$ & $43.7 \mathrm{~A}$ & $39.9 \mathrm{~A}$ & $29.2 \mathrm{~B}$ & \\
\hline \multicolumn{6}{|l|}{ ANOVA } \\
\hline Effect & $p$ & & & & \\
\hline Subculture & $<0.001$ & & & & \\
\hline PGR & $<0.001$ & & & & \\
\hline Subculture $x$ PGR & 0.04 & & & & \\
\hline
\end{tabular}

Means in columns marked with the same small letter did not differ significantly at $p=0.05$; Duncan's test; Means in row marked with the same capital letter did not differ significantly at $p=0.05$; Duncan's test. 
Table 2. Effect of PGRs on the production of somatic embryos longer than $10 \mathrm{~mm}$ in successive subcultures, the basal medium contained 2,4-D at the concentration of $0.1 \mathrm{mg} \mathrm{L}^{-1}$ in the first subculture and 0.01 in the remaining subcultures.

\begin{tabular}{|c|c|c|c|c|c|}
\hline \multirow[t]{2}{*}{$\begin{array}{c}\text { PGRs } \\
\left(\mathrm{mg} \mathrm{L}^{-1}\right)\end{array}$} & \multicolumn{4}{|c|}{$\begin{array}{c}\text { Number of Embryos with Cotyledon Length }> \\
10 \mathrm{~mm} \text { at the End of Consecutive Two-Month } \\
\text { Subcultures/100 mg Callus }\end{array}$} & \multirow[b]{2}{*}{ Mean } \\
\hline & 1 & 2 & 3 & 4 & \\
\hline TDZ 0.1 & $2.5 \mathrm{~b}$ & $5.8 \mathrm{~b}$ & $8.8 \mathrm{~cd}$ & $2.3 \mathrm{~cd}$ & $4.8 \mathrm{e}$ \\
\hline TDZ 0.5 & $13.3 \mathrm{a}$ & $9.5 \mathrm{~b}$ & $17.5 \mathrm{ab}$ & $10 \mathrm{c}$ & $12.6 \mathrm{bc}$ \\
\hline BAP 0.1 & $9.8 \mathrm{ab}$ & $22.3 \mathrm{a}$ & $25.8 \mathrm{a}$ & $32.5 \mathrm{a}$ & $22.6 \mathrm{a}$ \\
\hline BAP 0.5 & $8.3 \mathrm{ab}$ & $11.8 \mathrm{~b}$ & $15.5 \mathrm{bc}$ & $22.3 \mathrm{~b}$ & $14.4 \mathrm{~b}$ \\
\hline TDZ 0.1 + BAP 0.1 & $1.3 \mathrm{~b}$ & $6.8 \mathrm{~b}$ & $14.8 \mathrm{bc}$ & $21.8 \mathrm{~b}$ & $11.1 \mathrm{bc}$ \\
\hline TDZ $0.1+$ BAP 0.5 & $4.0 \mathrm{~b}$ & $9.5 \mathrm{~b}$ & $19.5 \mathrm{ab}$ & $23.8 \mathrm{~b}$ & $14.2 \mathrm{~b}$ \\
\hline TDZ $0.1+$ m-T 0.1 & $4.8 \mathrm{ab}$ & $8.0 \mathrm{~b}$ & $15.3 \mathrm{bc}$ & $8.8 \mathrm{~cd}$ & $9.2 \mathrm{~cd}$ \\
\hline TDZ $0.1+$ m-T 0.5 & $6.5 \mathrm{ab}$ & $5.2 \mathrm{~b}$ & $15.5 \mathrm{bc}$ & $10 \mathrm{c}$ & $9.3 \mathrm{~cd}$ \\
\hline TDZ $0.1+\mathrm{GA}_{3} 0.1$ & $4.8 \mathrm{ab}$ & $7.5 \mathrm{~b}$ & $6.8 \mathrm{~cd}$ & $5.3 \mathrm{~cd}$ & $6.1 \mathrm{de}$ \\
\hline $\mathrm{TDZ} 0.1+\mathrm{GA}_{3} 1$ & $2.3 \mathrm{~b}$ & $3.8 \mathrm{~b}$ & $2.8 \mathrm{~d}$ & $0.5 \mathrm{~d}$ & $2.3 \mathrm{e}$ \\
\hline Mean & $5.7 \mathrm{C}$ & $9.0 \mathrm{~B}$ & $14.2 \mathrm{~A}$ & $13.7 \mathrm{~A}$ & \\
\hline \multicolumn{6}{|l|}{ ANOVA } \\
\hline Effect & $p$ & & & & \\
\hline Subculture & $<0.001$ & & & & \\
\hline PGR & $<0.001$ & & & & \\
\hline Subculture $x$ PGR & $<0.001$ & & & & \\
\hline
\end{tabular}

Means in columns marked with the same small letter did not differ significantly at $p=0.05$; Duncan's test. Means in row marked with the same capital letter did not differ significantly at $p=0.05$; Duncan's test; $p$-probability of $F$ statistic from ANOVA.

The effectiveness of the bulb formation depended on the conditions in which the embryos had developed earlier (Table 3). The highest number of plantlets (10.1) with cotyledons longer than $10 \mathrm{~mm}$ were obtained following treatment with BAP applied alone at a lower concentration of $0.1 \mathrm{mg} \mathrm{L}^{-1}$. Such plants were than able to form the highest number of bulbs per $100 \mathrm{mg}$ callus (5.56) with the high efficiency of approximately 55\% (Table 3, Figure 7d,e). Thus starting from $1.6 \mathrm{~g}$ of embryogenic callus, 89 bulbs with a mean FM of $174 \mathrm{mg}$ were produced within 17.5 months of culture ( 8.5 months of embryo production +9 months of bulb formation process). While with TDZ alone at 0.1 and $0.5 \mathrm{mg} \mathrm{L}^{-1}$, only 2 and 11 bulbs were produced, respectively.

During ex vitro cultivation approximately $70-90 \%$ of bulbs developed into plants having one leaf and produced one daughter bulb larger than the initial bulb by $40-50 \%$ (Figure 7e).

Histological sections using different developmental stages of embryogenic calli showed that the development of somatic embryos was generally initiated through the division of superficial cells of callus. The embryogenic calli were comprised of a small volume, of regular shape and closely arranged cells, which were characterized by dense cytoplasm and large nuclei. Intensive cell division of embryonic cells was observed within the surface of the callus, leading to embryonic body development (Figure 8a,b). Globular embryos were formed either in clumps or singly. Their surface was covered by the distinct layer of protoderm provided the isolation layer for the embryo (Figure 8c,d). Later on, numerous embryogenic cell clusters (ET) were also formed internally in calli through the division of parenchyma cells inside the tissue (Figure $8 \mathrm{c}, \mathrm{d}$ ).

The scheme representing implemented experiments including the optimal conditions for particular stages of SE is shown in Table 4. 
Table 3. Post effect of PGRs on bulb formation.

\begin{tabular}{|c|c|c|c|c|c|c|}
\hline \multirow{2}{*}{$\begin{array}{c}\begin{array}{c}\text { PGRs } \\
\left(\mathbf{m g ~ L}^{-1}\right)\end{array} \\
\text { TDZ } 0.1\end{array}$} & \multicolumn{2}{|c|}{$\begin{array}{l}\text { Number of Plantlets Forming } \\
\text { Bulbs Per } 100 \mathrm{mg} \text { Callus } \\
\text { (Total Number of Plantlets } \\
\text { Forming Bulbs Obtained from } \\
1.6 \mathrm{~g} \text { of Callus) }\end{array}$} & \multicolumn{2}{|c|}{$\begin{array}{c}\text { Number of Bulbs Per } \\
100 \mathrm{mg} \text { Callus } \\
\text { (Total Number of Bulbs } \\
\text { Obtained from } 1.6 \mathrm{~g} \text { of Callus) }\end{array}$} & \multirow{2}{*}{$\begin{array}{c}\begin{array}{c}\text { Plantlets } \\
\text { Forming Bulbs } \\
(\%)\end{array} \\
22.2\end{array}$} & \multirow{2}{*}{$\begin{array}{c}\begin{array}{c}\text { Mean Bulb FM } \\
\text { (mg) }\end{array} \\
239.1 \mathrm{ab}\end{array}$} \\
\hline & $0.56 \mathrm{~d}$ & (9) & $0.13 \mathrm{~d}$ & (2) & & \\
\hline TDZ 0.5 & $3.56 \mathrm{c}$ & (57) & $0.69 \mathrm{~d}$ & (11) & 19.3 & $53.7 \mathrm{~d}$ \\
\hline BAP 0.1 & $10.1 \mathrm{a}$ & $(162)$ & $5.56 \mathrm{a}$ & (89) & 54.9 & $174 \mathrm{~b}$ \\
\hline TDZ 0.1 + BAP 0.1 & $6.69 \mathrm{~b}$ & (107) & $2.19 \mathrm{c}$ & (35) & 32.7 & 189. $0 \mathrm{ab}$ \\
\hline TDZ 0.1 + BAP 0.5 & $7.19 \mathrm{~b}$ & (115) & $2.38 \mathrm{c}$ & (38) & 33.0 & $223.9 \mathrm{ab}$ \\
\hline TDZ $0.1+\mathrm{m}-\mathrm{T} 0.1$ & $6.81 \mathrm{~b}$ & (109) & $1.88 \mathrm{c}$ & (30) & 27.5 & $190.6 \mathrm{ab}$ \\
\hline TDZ $0.1+\mathrm{m}-\mathrm{T} 0.5$ & $2.19 \mathrm{c}$ & (35) & $0.56 \mathrm{~d}$ & (9) & 25.7 & $312.5 \mathrm{a}$ \\
\hline TDZ 0.1 + GA3 0.1 & $2.38 \mathrm{c}$ & (38) & $0.56 \mathrm{~d}$ & (9) & 23.7 & $111.3 \mathrm{~cd}$ \\
\hline TDZ 0.1 + GA3 1 & - & - & - & - & - & - \\
\hline
\end{tabular}
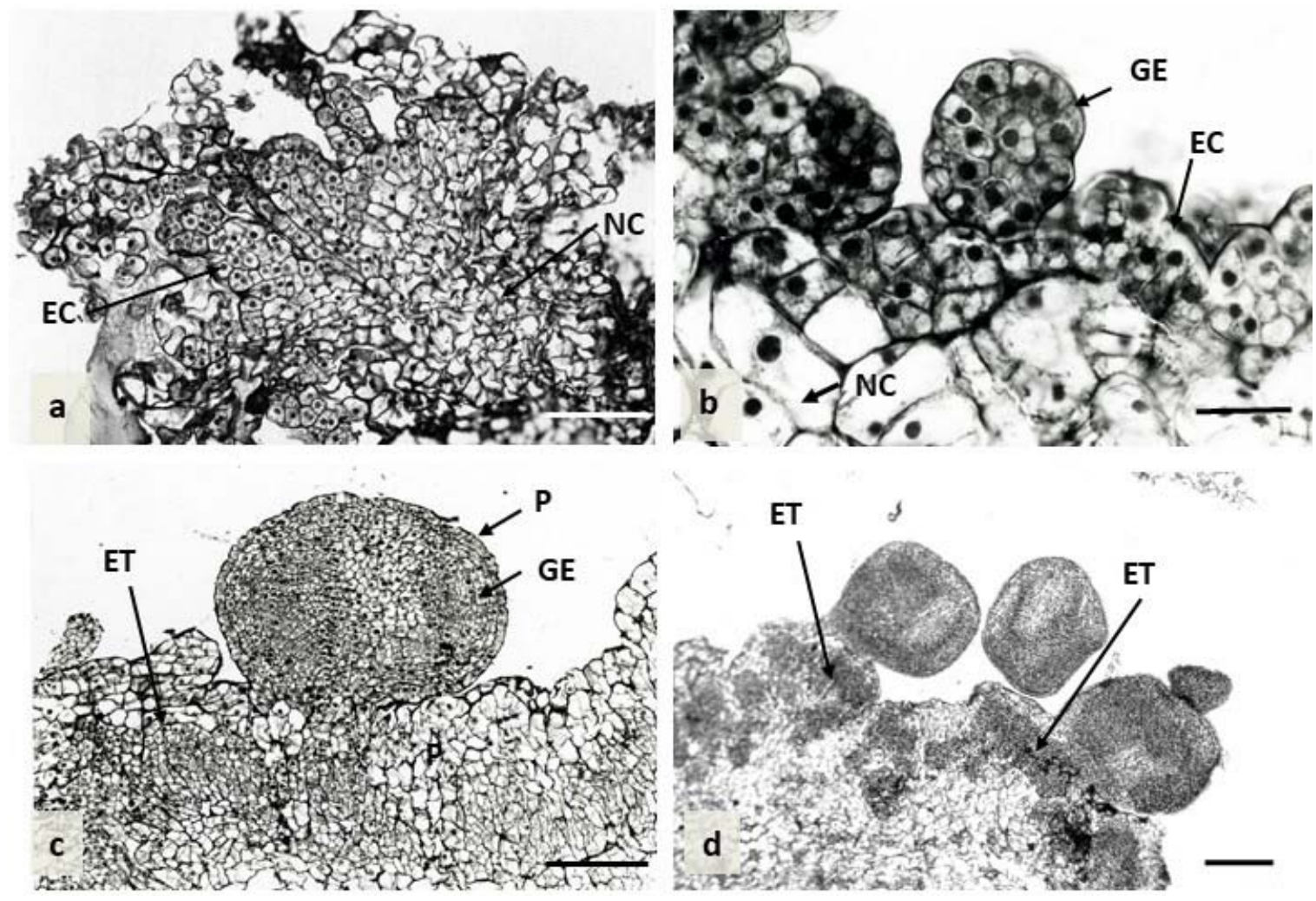

Figure 8. Histological analysis of embryogenic callus differentiation in 'Blue Parrot' on medium containing 2,4-D combined with TDZ at the concentrations of $0.1 \mathrm{mg} \mathrm{L}^{-1}$. (a) Embryogenically induced epidermal cells. (b) Details of the outer surface of callus. Embryogenic cells are characterized by the presence of a large nucleus and dense cytoplasm. (c) Single globular embryo. (d). Nodular callus formation with numerous embryogenic cell clusters at the surface callus. Abbreviations: EC-embryonic callus, ET-embryogenic cell clusters, GE-globular embryo, NC—non-proliferating callus, $p$-protoderm; Scale bar: $a, c, d=200 \mu \mathrm{m} ; \mathrm{b}=25 \mu \mathrm{m}$. 
Table 4. Scheme showing the course of experiments in the subsequent stages of the SE of tulip, the growth regulators used, the light/dark conditions and the duration of the successive stages; the optimal conditions for particular stages of SE were also indicated. For callus and direct SE induced on initial explants (first stage), three cultivars were used: 'Blue Parrot', 'Apeldoorn' and 'Prominence'; during the second stage, stabilization of embryogenic callus, of these three cultivars, the highest amount of embryogenic callus, sufficient for the investigations was obtained only for 'Blue Parrot' which was then used for the experiments.

\begin{tabular}{|c|c|c|c|}
\hline No. & SE Stages & $\begin{array}{l}\text { PGRs and Additives } \\
\qquad\left(\mathrm{mg} \mathrm{L}^{-1}\right)\end{array}$ & $\begin{array}{l}\text { Number and Duration of } \\
\text { the Subcultures, } \\
\text { Darkness/Light }\end{array}$ \\
\hline 1 & $\begin{array}{l}\text { Induction of callus and direct } \\
\text { embryo formation on initial } \\
\text { explants (flower stem fragments) }\end{array}$ & $\begin{array}{l}\text { TDZ 0, } 0.01,0.5 \\
\text { 2,4-D 2.5, } \\
\text { NAA 10, } \\
\text { or picloram } 2.5\end{array}$ & $\begin{array}{l}1 \times 2 \text { months } \\
\text { darkness }\end{array}$ \\
\hline 2 & $\begin{array}{l}\text { Stabilization and proliferation of } \\
\text { embryogenic callus }\end{array}$ & $\begin{array}{c}\text { TDZ 0.01, } 0.5 \\
2,4-D \text { 2.5, } \\
\text { NAA 10, } \\
\text { or picloram } 2.5 \\
\text { Optimal 2,4-D 2.5 + TDZ } 0.1 \text { and } 0.5 \\
\text { Darkness }\end{array}$ & $\begin{array}{l}6 \times 1 \text { month } \\
\text { darkness }\end{array}$ \\
\hline 3 & Optimization of callus production & $\begin{array}{c}\text { 2,4-D 2,5 + TDZ } 0.1 \\
\text { Proline (100 and 200), Tytanit }{ }^{\circledR}(10 \text { and 100) } \\
\text { Optimal: proline } 100 \text { alone or combined } \\
\text { with Tytanit }{ }^{\circledR}\end{array}$ & $\begin{array}{l}2 \times 1 \text { month } \\
\text { darkness }\end{array}$ \\
\hline 4 & $\begin{array}{l}\text { Somatic embryo formation } \\
\text { from callus }\end{array}$ & $\begin{array}{c}\text { Experiment } 1 . \\
\text { 2,4-D 0.1 + TDZ } 0.1 \\
\text { Proline 100, 200, 400; tyrosine } 100 \\
\text { White and red light } \\
\text { Optimal: proline } 100 \\
\text { Experiment } 2 \text {. } \\
\text { 2,4-D at } 0.1 \text { in 1st subculture then at } 0.01 \text { in } \\
\text { 2nd, 3rd and 4th subculture } \\
\text { + proline } 100 \\
\text { + PGRs: TDZ and BAP at } 0.1 \text { and } 0.5 \text { alone } \\
\text { and in combination: TDZ + BAP, } \\
\text { TDZ + m- } \mathrm{T} \text {, } \\
\text { TDZ + GA } 3 \\
\text { Optimal for embryo production: TDZ } 0.1 \\
\text { combined with BAP or m-T each at } 0.5 \\
\text { Optimal for embryo conversion: BAP } 0.1 ; \\
\text { darkness }\end{array}$ & $\begin{array}{c}2 \times 2 \text { months in darkness }+ \\
2 \times 2 \text { months in white/red light } \\
4 \times 2 \text { months } \\
\text { darkness }\end{array}$ \\
\hline 5 & Preparation for bulb formation & $\begin{array}{c}\text { 2.,4-D and BAP at } 0.1 \text { for } 2 \text { months, } \\
\text { then addition of a liquid medium } \\
\text { containing NAA } 1 \text { and ancymidol } 1 \text { for } \\
1.5 \text { months }\end{array}$ & $\begin{array}{c}1 \times(2 \text { month }+1.5 \text { months }) \\
\text { light }\end{array}$ \\
\hline 6 & $\begin{array}{l}\text { Induction of bulb formation process } \\
\left(\text { cooling at } 5^{\circ} \mathrm{C}\right)\end{array}$ & PGR-free medium with $7 \%$ sucrose & $\begin{array}{c}1 \times 3 \text { months } \\
\text { darkness }\end{array}$ \\
\hline 7 & Bulb formation & $\begin{array}{l}\text { The same PGR-free medium with } \\
7 \% \text { sucrose }\end{array}$ & $1 \times 2.5$ monthslight \\
\hline
\end{tabular}

\section{Discussion}

\subsection{SE Induction and Embryo Development}

In our study, embryogenic calli capable of continuous multiplication were derived from yellowish-white callus with a granular structure, formed on the cut surface of flower stem - from the tissues of the vascular bundles, in the presence of 2,4-D and TDZ. Similar callus formation and SE initiation from cells surrounding the veins have frequently been observed for various plant species, as reviewed by Fehér [22]. It should be noted that we used 2,4-D at a higher concentration for induction of such granular callus but this auxin at much lower concentration was effective for further callus multiplication with simultaneous embryo formation. This corresponds with a report on carrot SE 
induced in liquid cultures from single cells or cell clusters of perivascular origin [30]. It was suggested, based on several reports that in the presence of 2,4-D, these cells formed pro-embryogenic cell masses as a transitional state leading to SE. In turn, removal of the auxin was a signal for embryo formation from pro-embryogenic masses [22].

The results of the current research revealed that the highest numbers of embryos directly regenerated on initial explants were recorded for 2,4-D or NAA combined with TDZ while auxins alone purely induced SE. Furthermore, we observed lower numbers of tulip embryos in the presence of picloram, even when it was combined with TDZ, unlike in other species such as Lachenalia viridiflora [31], Cyrtanthus mackenii [32], Manihot esculenta [33] and Lilium sp. [34].

As in the present study, the strong morphogenetic effect of TDZ was also observed in our earlier studies in which TDZ combined with NAA was essential for the cyclic multiplication of tulip adventitious shoots [11]. A similar PGR combination was used to induce the direct formation of adventitious shoots from vegetative buds isolated from uncooled bulbs of tulip 'Apeldoorn' [35] and generative seedlings of Tulipa kaufmanniana [36]. These correspond to numerous reports, which showed that TDZ, a derivative of diphenylurea with cytokinin-like activity, induces morphogenetic processes much more strongly than purine cytokinins [37,38]. The strong activity of TDZ is attributed to its direct action through binding to cytokinin receptors [39] or indirectly via increasing the accumulation of endogenous cytokinins by inhibiting the activity of cytokinin oxidase/dehydrogenase (CKX) [40]. This highly active PGR in combination with auxins has often been used to induce the formation of callus, embryos or adventitious shoots in vitro in species commonly considered "difficult" for in vitro regeneration [38].

In our research, the yield of the embryos produced in the process of cyclic multiplication of embryogenic callus using $0.5 \mathrm{~g} \mathrm{~L}^{-1} \mathrm{TDZ}$ combined with 2,4-D (0.01-0.1 $\left.\mathrm{mg} \mathrm{L}^{-1}\right)$ was very high, reaching 94.3 embryos per $100 \mathrm{mg}$ of callus at the second subculture. However, in the following stages, some of the developing embryos died, and only $18.6 \%$ of them were able to develop cotyledons longer than $10 \mathrm{~mm}$, capable of forming bulbs with an efficiency of 19.3\%. Whereas, Ptak and Bach [26] obtained at most 7.9 embryos per $1 \mathrm{~g}$ of callus in the presence of $25 \mu \mathrm{M}$ picloram in combination with $0.5 \mu \mathrm{M}$ BAP. These authors, however, did not report on the formation of bulbs. In our study, embryo conversion into plant was positively influenced by BAP applied at a lower concentration of $0.1 \mathrm{mg} \mathrm{L}^{-1}$ combined with decreased 2,4-D concentration to 0.1 (in the first subculture) and then to $0.01 \mathrm{mg} \mathrm{L}^{-1}$ (in subsequent subcultures). For this treatment, a three-fold higher bulb number was obtained (5.56 bulbs per $100 \mathrm{mg}$ of callus). Similarly, BAP combined with NAA was more effective for either SE induction or embryo conversion into plants in several ornamental geophytes such as Hippeastrum hybridum, Eucharis grandiflora and Crinum asiaticum [41]. Furthermore, NAA was ineffective when used alone. Unlike tulip, Hippeastrum and Eucharis were completely unresponsive to 2,4-D. Large differences among plant species and cultivars in SE responses to auxin type and other PGRs have been observed in numerous studies $[19,23]$. The process of SE is a complex multifactorial system controlled by exogenous stress factors and PGRs, mainly auxins alone or combined with cytokinins during early SE stages. Other PGRs such as ethylene, abscised acid and gibberellins regulate further embryo development (maturation or conversion into plants) [21].

In our study, TDZ combined with $\mathrm{GA}_{3}$ negatively influenced embryo production and conversion into plants. However, we used $\mathrm{GA}_{3}$ continuously during embryogenic callus multiplication and the simultaneous embryo formation. In gladiolus, $\mathrm{GA}_{3}$ addition at $0.5 \mathrm{mg} \mathrm{L}^{-1}$ stimulated embryo development at later phases such as maturation and conversion into a plant. This indicates GA's positive action on embryo development when applied in later stages. On the other hand, GA was reported to either inhibit or stimulate SE depending on the plant species as reviewed by Joshi and Kumar [19].

Organic nitrogen sources such as casein hydrolysate and amino acids, especially glutamine have been considered to have a positive effect on SE [42,43]. In our study, the basal medium contained casein hydrolysate and glutamine. In addition, we found that another amino acid such as proline significantly increased either embryogenic callus production rate or embryo development. Proline is reported to 
stimulate SE of many species, e.g., maize [44,45] and ginseng [46]. Gerdakaneh et al. [47] showed that proline at $100 \mathrm{mg} \mathrm{L}^{-1}$ was much more effective than glutamine and alanine at induction and development of somatic embryos of strawberry. These authors suggested that the strong action of proline on SE could be related to improved cell signaling since this amino acid is associated with several signal transduction pathways. Perhaps the beneficial effect of proline is also related to the role of arabinogalactans in the formation of somatic embryos. These proteins reach in hydroxyproline are proteoglycans that are present in the cell membrane, the cell matrix and cell wall [48]. Arabinogalactans promoted SE of carrot [49]. Another amino acid, tyrosine was reported to stimulate somatic embryo formation in cassava [33]. However, in our study, we did not observe any positive effect of this amino acid.

In addition, we examined the effect of Tytanit ${ }^{\circledR}$ on SE since this fertilizer (containing titanium (Ti) at $0.8 \%$ concentration) was reported to stimulate plant growth through increased nutrient uptake [50]. Słomka et al. [51] observed that Tytanit ${ }^{\circledR}$ decreased zygotic embryo abortions and increased seed set in distylous common buckwheat. In our study, this biostimulant $\left(10 \mathrm{mg} \mathrm{L}^{-1}\right)$ combined with proline (100 $\mathrm{mg} \mathrm{L}^{-1}$ ) significantly improved embryogenic callus production compared to control but its effect was not significantly different compared to proline used alone.

Our preliminary study showed that both callus production and adventitious shoot formation on flower stem fragments were strongly inhibited either in red or white light [52]. The results of the current study confirmed that light negatively influenced the regenerative potential of tulip cells. Furthermore, the red light was more inhibitory to SE. Embryo formation proceeded best in darkness that is indicated by the comparison of the results of our first and the second experiment on embryo development from callus. Thus, on the same medium containing proline at $100 \mathrm{mg} \mathrm{L}^{-1}$ and TDZ combined with 2,4-D, each at the concentration of $0.1 \mathrm{mg} \mathrm{L}^{-1}, 6.6$ and 3.9 embryos were obtained under white and red lights, respectively (used in the last two subcultures of the four ones, in the first experiment) whereas 13.8 embryos were recorded in the first subculture in the second experiment. The darkness during the initial regeneration of shoot-like structures of tulip was also recommended by Le Nard et al. [4] and Hulscher et al. [6]. In contrast, the beneficial effect of red light under continuous irradiation on the formation and multiplication of embryogenic callus and the somatic embryo development was demonstrated for several geophytes such as freesia, hyacinth, lily and cyclamen [53]. In turn, Yu et al. [54] have shown that red light promoted cotton embryonic callus formation by influencing the levels of endogenous hormones and polyamines, and activities of antioxidant enzymes, while in continuous darkness, no embryogenic callus was produced.

We present a complete system of tulip micropropagation through SE, starting from the initiation of embryogenic callus, via its cyclical multiplication and formation of somatic embryos, then their conversion into plants, and finally the formation of bulbs ready for ex vitro planting. In addition, the efficiency of somatic embryogenesis is higher than that presented by other authors who obtained somatic embryos only through direct regeneration on initial explants or from callus maintained for one or two subcultures $[24,26,28]$. These authors, however, did not present results on bulb formation.

\subsection{Morphology and Histology of Somatic Embryo Development}

Our histological analysis of somatic embryo formation from callus showed that embryos have either external or internal origins. Similarly, Yan et al. [34] documented two pathways of somatic embryo development in Lilium. This may be important in improving the efficiency of SE. In contrast, in Lachenalia virdiflora, the development of somatic embryos was initiated at the surface of embryogenic calli [31]. Regardless of the place of initiation of divisions, the embryogenic cells were characterized by a prominent nucleus with dense cytoplasm [31,34]. Globular embryos were covered with the protoderm. Similar findings have been reported by Yan et al. [34] for somatic embryos in Lilium, and the authors believed that protoderm provided the physiological isolation layer required for somatic embryo development. The division of the globular embryo continued, and they enlarged, reaching the cotyledon stage. Our observations showed that longitudinal structures formed in the dark, when transferred to a medium with a lower TDZ and 2,4-D concentration, and placed in the 
light at a 16-h photoperiod, developed into characteristic forms during the long-lasting process which four successive phases could be distinguished: (1) the development of an upward-growing cotyledon; (2) formation of a radicle (that never developed further) at the base of the cotyledon (these two phases were in the dark during the first two months), (3) development of a shortened or longer stolon growing downwards into the medium and (4) development of one or more vegetative bud meristems at the stolon tip (they developed in the third and fourth month of the initial culture).

Further process of somatic embryo formation in a tulip was similarly described by Gude and Dijkema [24] and by Maślanka and Bach [27]. As in our study, these authors also did not observe the development of the embryonic root. The formation of regular structures: the cotyledon and the stolon at its opposite pole resembled the development of a zygotic embryo, as described by Niimi [55]. The difference in the structures developing in vitro compared to the zygotic embryos was the lack of development of the embryonic root in the former. This author reported that the tulip zygotic embryo in a seed is not fully mature; there is no radicle and no apical shoot meristem. For the proper development of radicle and shoot, low-temperature treatment is required to break dormancy. The author showed that a radicle appears after 40 days of cooling at $4{ }^{\circ} \mathrm{C}$ and a bud meristem forms a stolon tip after 70 days, then, bulb develops from this bud. In the immature, not yet cooled zygotic embryo, two vascular bundles were visible: one directed towards the cotyledon tip and the other downwards towards the stolon tip. In our study, two similar vascular tissues were observed in the somatic embryo developing in vitro. All these observations indicate that the regeneration of specific structures on the initial explant was of somatic embryogenesis. At the same time, vegetative bud meristem formed on the stolon pol (in the presence of TDZ and at a temperature of $23^{\circ} \mathrm{C}$ ) and developed into a shoot. As for the reasons for the inhibition of the embryonic root development, it can be assumed that this was due to the lack of low-temperature treatment and the presence of TDZ in the medium, which strongly inhibits root formation [14].

\section{Conclusions}

An efficient method of tulip regeneration via SE has been developed. This system is based on the cyclic multiplication of the embryogenic callus with the simultaneous formation of embryos. The process of the callus proliferation and embryo production is most efficient when it is running in darkness on a medium containing 2,4-D $0.01 \mathrm{mg} \mathrm{L}^{-1}$ and TDZ or BAP alone or in combination, enriched with $100 \mathrm{mg} \mathrm{L}^{-1}$ proline. Using these PGRs and proline supplementation, it is possible to obtain on average from 30 to 55 embryos per $100 \mathrm{mg}$ callus. More embryos (capable of forming bulbs) with longer, well developed cotyledons are obtained in the presence of 2,4-D and BAP at low concentrations, 0.01 and $0.1 \mathrm{mg} \mathrm{L}^{-1}$, respectively. However, the stage preceding the formation of bulbs, in which the embryos develop into plants, and the stage of bulb formation, require further optimization in order to increase efficiency of bulbing process over $55 \%$, obtained in the presented studies.

Histological analysis has confirmed the embryonic nature of the callus and clarified embryo development on the medium containing 2,4-D combined with TDZ at the concentrations of $0.1 \mathrm{mg} \mathrm{L}^{-1}$.

Supplementary Materials: The following are available online at http://www.mdpi.com/2073-4395/10/12/1857/s1, Table S1: Probability value (P) of F test from three-way analysis of variance (ANOVA) of callus and somatic embryo induction on tulip initial explants depending on auxin type, TDZ concentration and cultivar, Table S2: Means of the callus growth and somatic embryo number regenerated on initial explants for tulip cultivars, auxin types and TDZ concentrations; three-way ANOVA.

Author Contributions: Conceptualization, M.P.; funding acquisition, A.M.-C.; investigation, M.P., A.M.-C.; methodology, M.P., A.M.-C.; project administration, M.P.; resources, M.P. and A.M.-C.; supervision, M.P.; writing_-original draft, M.P., A.M.-C.; writing_review and editing, M.P., A.M.-C. All authors have read and agreed to the published version of the manuscript.

Funding: The study was funded by the Polish Ministry of Science and Higher Education through statutory funds (ZBS/8/2016) of the Research Institute of Horticulture, Skierniewice, Poland.

Acknowledgments: The authors express their gratitude to Robert Maciorowski for support in statistical analysis.

Conflicts of Interest: The authors declare no conflict of interest. 


\section{References}

1. Orlikowska, T.; Podwyszyńska, M.; Marasek-Ciołakowska, A.; Sochacki, D.; Szymański, R. Tulip. In Ornamental Crops; Springer: Cham, Switzerland, 2018; pp. 769-802.

2. Marasek-Ciolakowska, A.; Nishikawa, T.; Sheaand, D.J.; Okazaki, K. Breeding of lilies and tulips-Interspecific hybridization and genetic background. Breed. Sci. 2018, 68, 35-52. [CrossRef] [PubMed]

3. Rice, R.D.; Alderson, P.G.; Wright, N.A. Induction of bulbing of tulip shoots in vitro. Sci. Hort. 1983, 20, 377-390. [CrossRef]

4. Le Nard, M.; Ducommun, C.; Weber, G.; Dorion, N.; Bigot, C. Obsevations sur la multiplication in vitro de la tulipe (Tulipa gesneriana L.) à partir de hampes florales prélevées chez des bulbes en cours de conservation. Agronomie 1987, 7, 321-329. [CrossRef]

5. Alderson, P.G.; Taeb, A.G. Effect of bulb storage on shoot regeneration from floral stems of tulip in vitro. J. Hort. Sci. 1990, 65, 71-74.

6. Hulscher, M.; Krijksheld, H.T. Micropropagation of tulip. Acta Hort. 1992, 420, 104-105. [CrossRef]

7. Famelaer, I.; Ennik, E.; Eikelboom, W.; van Tuyl, J.M.; Creemers-Molenaar, J. The initiation of callus and regeneration from callus culture of Tulipa gesneriana. Plant Cell Tiss. Org. Cult. 1996, 47, 51-58. [CrossRef]

8. Kuijpers, A.M.; Langens-Gerrits, M. Propagation of tulip in vitro. Acta Hort. 1997, 430, 321-324. [CrossRef]

9. Maślanka, M.; Bach, A. Induction of bulb organogenesis in in vitro cultures of Tarda tulip (Tulipa tarda Stapf.) from seed-derived explants. Vitr. Cell. Dev. Biol. Plant. 2014, 50, 712-721. [CrossRef]

10. Kritskaya, T.A.; Kashin, A.S.; Kasatkin, M.Y. Micropropagation and somaclonal variation of Tulipa suaveolens (Liliaceae) in vitro. Russ. J. Dev. Biol. 2019, 50, 209-215. [CrossRef]

11. Podwyszyńska, M.; Marasek, A. Effect of thidiazuron and paclobutrazol on regeneration potential of flower stalk explants in vitro and subsequent shoot multiplication. Acta Soc. Bot. Pol. 2003, 72, 181-190. [CrossRef]

12. Podwyszyńska, M. Improvement of bulb formation in micropropagated tulips by treatment with NAA and paclobutrazol or ancymidol. Acta Hort. 2006, 725, 679-684. [CrossRef]

13. Podwyszyńska, M.; Sochacki, D. Micropropagation of tulip: Production of virus-free stock plants. In Protocols for in Vitro Propagation of Ornamental Plants, Methods in Molecular Biology 589 (Springer Protocols); Jain, S.M., Ochatt, S.J., Eds.; Humana Press/Springer: New York, NY, USA, 2010; pp. 243-256.

14. Podwyszyńska, M.; Novák, O.; Doležal, K.; Strnad, M. Endogenous cytokinin dynamics in micropropagated tulips during bulb formation process influenced by TDZ and iP pre-treatment. Plant Cell Tiss. Organ Cult. 2014, 119, 331-346. [CrossRef]

15. Sochacki, D.; Podwyszyńska, M. Virus eradication in narcissus and tulip by chemotherapy. In Floriculture and Ornamental Biotechnology 6. Special Issue Bulbous Ornamentals; Van Tuyl, J., Arens, P., Eds.; Global Science Book Ltd.: Ikenobe, Kagawa ken, Japan, 2012; pp. 114-121.

16. Podwyszyńska, M.; Trzewik, A.; Marasek-Ciolakowska, A. In vitro polyploidisation of tulips (Tulipa gesneriana L.)—Phenotype assessment of tetraploids. Sci. Hortic. 2018, 242, 155-163. [CrossRef]

17. Rose, R.J.; Mantiri, F.R.; Kurdyukov, S.; Chen, S.K.; Wang, X.D.; Nolan, K.E.; Sheahan, M.B. Developmental biology of somatic embryogenesis. In Plant Developmental Biology-Biotechnological Perspectives; Pua, E.C., Ed.; Springer: Berlin/Heidelberg, Germany, 2010; pp. 3-26.

18. Steward, F.C. Growth and organized development of cultured cells. III. Interpretations of the growth from free cell to carrot plant. Am. J. Bot. 1958, 45, 709-713. [CrossRef]

19. Joshi, R.; Kumar, P. Regulation of somatic embryogenesis in crops: A review. Agric. Rev. 2013, 34, 1-20.

20. Elhiti, M.; Stasolla, C.; Wang, A. Molecular regulation of plant somatic embryogenesis. Vitr. Cell. Dev. Biol. Plant 2013, 49, 631-642. [CrossRef]

21. Kumar, V.; van Staden, J. New insights into plant somatic embryogenesis: An epigenetic view. Acta Physiol. Plant. 2017, 39, 194. [CrossRef]

22. Fehér, A. Callus, dedifferentiation, totipotency, somatic embryogenesis: What these terms mean in the era of molecular plant biology? Front. Plant Sci. 2019, 10, 536. [CrossRef]

23. Mujib, A.; Ali, M.; Tonk, D.; Isah, T.; Zafar, N. Embryogenesis in ornamental monocots: Plant growth regulators as signalling element. In Somatic Embryogenesis in Ornamentals and Its Applications; Springer: New Delhi, India, 2016; pp. 187-201.

24. Gude, H.; Dijkema, M.H.G.E. Somatic embryogenesis in tulip. Acta Hort. 1997, 430, 275-280. [CrossRef] 
25. Bach, A.; Ptak, A. Somatic embryogenesis and plant regeneration from ovaries of Tulipa gesneriana L. in vitro cultures. Acta Hort. 2001, 560, 391-394. [CrossRef]

26. Ptak, A.; Bach, A. Somatic embryogenesis in tulip (Tulipa gesneriana L.) flower stem cultures. Vitr. Cell Dev. Biol. Plant. 2007, 43, 35-39. [CrossRef]

27. Maślanka, M.; Bach, A. Effect of abscisic acid, ethylene and inhibitors of their biosynthesis (fluridone and salicylic acid) on somatic embryos conversion in tulips. Ecol. Chem. Eng. 2010, 17, 1135-1140.

28. Maślanka, M.; Bach, A.; Janowiak, F. Endogenous ABA content in relation to maturation of somatic embryos in Tulipa (L.) 'Apeldoorn' cultures. Acta Physiol. Plant. 2016, 38, 270. [CrossRef]

29. Murashige, T.; Skoog, F. A revised medium for rapid growth and bio assays with tobacco tissue cultures. Physiol. Plant. 1962, 15, 473-497. [CrossRef]

30. Schmidt, E.D.; Guzzo, F.; Toonen, M.A.; De Vries, S.C. A leucine-rich repeat containing receptor-like kinase marks somatic plant cells competent to form embryos. Development 1997, 124, 2049-2062.

31. Kumar, V.; Moyo, M.; van Staden, J. Enhancing plant regeneration of Lachenalia viridiflora, a critically endangered ornamental geophyte with high floricultural potential. Sci. Hortic. 2016, 211, 263-268. [CrossRef]

32. Kumari, A.; Baskaran, P.; van Staden, J. In vitro propagation via organogenesis and embryogenesis of Cyrtanthus mackenii: A valuable threatened medicinal plant. Plant Cell Tiss. Organ Cult. 2017, 131, 407-415. [CrossRef]

33. Ubalua, A.O.; Mbanaso, E.N.A. Somatic embryogenesis in two Nigerian cassava cultivars (Sandpaper and TMS 60444). J. Evol. Biol. Res. 2014, 6, 9-12.

34. Yan, R.; Wang, C.; Wang, J.; Nie, R.; Sun, H. High-efficiency somatic embryogenesis techniques for different hybrids of cut lilies. Plant Cell Tiss. Organ Cult. 2020, 143, 145-157. [CrossRef]

35. Maślanka, M.; Bach, A. Tulip propagation in vitro from vegetative bud explants. Ann. Wars. Univ. Life Sci. SGGW Horticult. Landsc. Architect. 2013, 34, 21-26.

36. Yurievna, N.A.; Vladimirovna, G.L. The application of different reproduction techniques for rare species waterlily tulip (Tulipa kaufmanniana Regel.) propagation under ex situ conditions. Ornam. Hortic. 2019, 25, 450-460. [CrossRef]

37. Ahmad, N.; Faisal, M. Thidiazuron: From Urea Derivative to Plant Growth Regulator; Springer: Singapore, 2018; p. 491.

38. Dinani, E.T.; Shukla, M.R.; Turi, C.E.; Sullivan, J.A.; Saxena, P.K. Thidiazuron: Modulator of Morphogenesis In Vitro. In Thidiazuron: From Urea Derivative to Plant Growth Regulator; Springer: Singapore, 2018; pp. 1-36.

39. Spíchal, L.; Rakova, N.Y.; Riefler, M.; Mizuno, T.; Romanov, G.A.; Strnad, M.; Schmülling, T. Two cytokinin receptors of Arabidopsis thaliana, CRE1/AHK4 and AHK3, differ in their ligand specificity in a bacterial assay. Plant Cell. Physiol. 2004, 45, 1299-1305. [CrossRef]

40. Zatloukal, M.; Gemrotov, M.; Doležal, K.; Havlíček, L.; Spíchal, L.; Strnad, M. Novel potent inhibitors of A. thaliana cytokinin oxidase/dehydrogenase. Bioorg. Med. Chem. 2008, 16, 9268-9275. [CrossRef]

41. Mujib, A.; Banerjee, S.; Ghosh, P.D. Origin, Development and Structure of Somatic Embryosin Selected Bulbous Ornamentals: BAP as Inducer. In Somatic Embryogenesis; Springer: Berlin/Heidelberg, Germany, 2005; pp. 15-24.

42. Garin, É.; Bernier-Cardou, M.; Isabel, N.; Klimaszewska, K.; Plourde, A. Effect of sugars, amino acids, and culture technique on maturation of somatic embryos of Pinus strobus on medium with two gellan gum concentrations. Plant Cell Tiss. Organ Cult. 2000, 62, 27-37. [CrossRef]

43. Kim, Y.W.; Moon, H.K. Enhancement of somatic embryogenesis and plant regeneration in Japanese larch (Larix leptolepis). Plant Cell Tiss. Organ Cult. 2007, 88, 241-245. [CrossRef]

44. Armstrong, C.L.; Green, C.E. Establishment and maintenance of friable, embryogenic maize callus and the involvement of L-proline. Planta 1985, 164, 207-214. [CrossRef] [PubMed]

45. Pareddy, D.R.; Petolino, J.F. Somatic embryogenesis and plant regeneration from immature inflorescences of several elite inbreds of maize. Plant Sci. 1990, 67, 211-219. [CrossRef]

46. Nhut, D.T.; Vinh, B.V.T.; Hien, T.T.; Huy, N.P.; Nam, N.B.; Chien, H.X. Effects of spermidine, proline and carbohydrate sources on somatic embryogenesis from main root transverse thin cell layers of Vietnamese ginseng (Panax vietnamensis Ha et. Grushv.). Afr. J. Biotechnol. 2012, 11, 1084-1091.

47. Gerdakaneh, M.; Mozafari, A.A.; Sarabi, B. Effects of different amino acids on somatic embryogenesis of strawberry (Fragaria $\times$ ananassa Duch.). Acta Physiol. Plant. 2011, 33, 1847-1852. [CrossRef] 
48. Majewska-Sawka, A.; Nothnagel, E.A. The multiple roles of arabinogalactan proteins in plant development. Plant Physiol. 2000, 122, 3-10. [CrossRef]

49. Kreuger, M.; van Holst, G.J. Arabinogalactan proteins and plant differentiation. Plant Mol. Biol. 1996, 30, 1077-1086. [CrossRef] [PubMed]

50. Kleiber, T.; Markiewicz, B. Application of "Tytanit" in greenhouse tomato growing. Acta Sci. Pol. Hortorum Cultus 2013, 12, 117-126.

51. Słomka, A.; Michno, K.; Dubert, F.; Dziurka, M.; Kopeć, P.; Płażek, A. Embryological background of low seed set in distylous common buckwheat (Fagopyrum esculentum Moench) with biased morph ratios, and biostimulant-induced improvement of it. Crop Pasture Sci. 2017, 68, 680-690. [CrossRef]

52. Podwyszyńska, M.; Rojek, A. Wpływ jakości światła i ciemności na regeneracje tulipana (Tulipa gesneriana L.) in vitro. Zesz. Nauk. Inst. Sadow. Kwiac. 2000, 7, 129-137.

53. Bach, A.; Malik, A.; Ptak, A.; Kędra, M. Light effects on ornamental microplant shoots and bulbs quality. Acta Hort. 2000, 530, 173-179. [CrossRef]

54. Yu, Y.; Qin, W.; Li, Y.; Zhang, C.; Wang, Y.; Yang, Z.; Li, F. Red light promotes cotton embryogenic callus formation by influencing endogenous hormones, polyamines and antioxidative enzyme activities. Plant Growth Regul. 2019, 87, 187-199. [CrossRef]

55. Niimi, Y. Histological observations on the initiation of the vegetative apex in tulip seeds cultured under low temperatures. Sci. Hort. 1980, 13, 161-171. [CrossRef]

Publisher's Note: MDPI stays neutral with regard to jurisdictional claims in published maps and institutional affiliations. 